\title{
Exosomes: biogenesis, biologic function and clinical potential
}

\author{
Yuan Zhang ${ }^{1}$, Yunfeng Liư ${ }^{2}$ Haiying Liu ${ }^{2 *}$ and Wai Ho Tang ${ }^{1 *}$
}

\begin{abstract}
Exosomes are nano-sized biovesicles released into surrounding body fluids upon fusion of multivesicular bodies and the plasma membrane. They were shown to carry cell-specific cargos of proteins, lipids, and genetic materials, and can be selectively taken up by neighboring or distant cells far from their release, reprogramming the recipient cells upon their bioactive compounds. Therefore, the regulated formation of exosomes, specific makeup of their cargo, cell-targeting specificity are of immense biological interest considering extremely high potential of exosomes as non-invasive diagnostic biomarkers, as well as therapeutic nanocarriers. In present review, we outline and discuss recent progress in the elucidation of the regulatory mechanisms of exosome biogenesis, the molecular composition of exosomes, and technologies used in exosome research. Furthermore, we focus on the potential use of exosomes as valuable diagnostic and prognostic biomarkers for their cell-lineage and state-specific contents, and possibilities as therapeutic vehicles for drug and gene delivery. Exosome research is now in its infancy, in-depth understanding of subcellular components and mechanisms involved in exosome formation and specific cell-targeting will bring light on their physiological activities.
\end{abstract}

Keywords: Exosome, Biogenesis, Biomarker, Therapeutic vehicle

\section{Introduction}

Exosomes are small endosomal derived membrane microvesicles that have observed increasing attentions over the past decade. The presence of exosomes in extracellular space was identified as early as in late 1980s [1]. However, exosomes secreted from cells were initially proposed as cellular waste resulting from cell damage, or by-products of cell homeostasis, and have no significant impact on neighboring cells. It is only recently that these extracellular vesicles are functional vehicles that carry a complex cargo of proteins [2], lipids [3], and nucleic aids $[2,4,5]$, be capable of delivering these cargos to the target cells they encounter, which may ultimately reprogram the recipient cells distal from their release. Thus, exosomes represent a novel mode of intercellular communication,

\footnotetext{
*Correspondence: xiangliuhaiying@aliyun.com; waiho.tang@gwcmc.org ${ }^{1}$ Institute of Pediatrics, Guangzhou Women and Children's Medical Center, Guangzhou Medical University, Guangzhou 510623, Guangdong, China

${ }^{2}$ Clinical Laboratory Department, Guangzhou Women and Children's Medical Center, Guangzhou Medical University, Guangzhou 510623, Guangdong, China
}

which may play a major role in many cellular processes, such as immune response [6], signal transduction [7], antigen presentation [8]. As exosomes can be released by practically all eukaryotic cells, it is well considered that their cargos may greatly differ from each other for function of the originated cell types and their current state (e.g. transformed, differentiated, stimulated, and stressed). Thus, exosomes and their biologically active cargos may offer prognostic information in a range of diseases, such as chronic inflammation [9], cardiovascular and renal diseases $[10,11]$, neurodegenerative diseases [12], lipid metabolic diseases [13] and tumors [14].

In this review, we endeavor to provide a brief description of exosome biogenesis, molecular properties, and exosomal functional activities in cell-cell communications, as established to date. In addition, strategies for their isolation and characterization also be summarized. Finally, we discuss the feasibility of exosomes as clinical biomarkers and therapeutic potential of engineered exosomes as vehicles for targeted therapy.

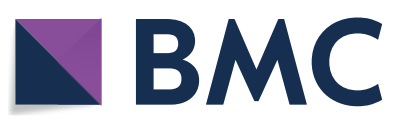

(c) The Author(s) 2019. This article is distributed under the terms of the Creative Commons Attribution 4.0 International License (http://creativecommons.org/licenses/by/4.0/), which permits unrestricted use, distribution, and reproduction in any medium, provided you give appropriate credit to the original author(s) and the source, provide a link to the Creative Commons license, and indicate if changes were made. The Creative Commons Public Domain Dedication waiver (http://creativecommons.org/ publicdomain/zero/1.0/) applies to the data made available in this article, unless otherwise stated. 


\section{Exosome biogenesis}

Exosomes are constitutively generated from late endosomes, which are formed by inward budding of the limited multivesicular body (MVB) membrane. Invagination of late endosomal membranes results in the formation of intraluminal vesicles (ILVs) within large MVBs [15]. During this process, certain proteins are incorporated into the invaginating membrane, while the cytosolic components are engulfed and enclosed within the ILVs. Most ILVs are released into the extracellular space upon fusion with the plasma membrane, which are referred to as "exosomes" [16, 17]. Alternatively, these components are trafficked to lysosomes for degradation. Canonical exosomes display a particular biconcave or cup-like shape when produced by artificially drying during preparation, while they appear spheroid in solution under transmission electron microscopy [18]. Typically, they have a density range from $1.13 \mathrm{~g} / \mathrm{mL}$ (B cell-derived exosomes) [19] up to $1.19 \mathrm{~g} / \mathrm{mL}$ (epithelial cell-derived exosomes) [20] on sucrose gradients.

Evidence has revealed that the formation of ILVs requires the endosomal sorting complex required for transport (ESCRT) function. It is an intricate protein machinery composed of four separate protein ESCRTs (0 through III) that work cooperatively to facilitate MVB formation, vesicle budding, and protein cargo sorting [21, 22]. The ESCRT mechanism is initiated by recognition and sequestration of ubiquitinated proteins to specific domains of the endosomal membrane via ubiquitinbinding subunits of ESCRT-0. After interaction with the ESCRT-I and -II complexes, the total complex will then combine with ESCRT-III, a protein complex that is involved in promoting the budding processes. Finally, following cleaving the buds to form ILVs, the ESCRT-III complex separates from the MVB membrane with energy supplied by the sorting protein Vps4 [21]. Despite the controversy of whether exosome release is an ESCRTregulated mechanism, different ESCRT components and ubiquitinated proteins have already been identified in exosomes isolated from various cell types. Additionally, the typical exosomal protein Alix, which is associated with several ESCRT (TSG101 and CHMP4) proteins, has been reported to participate in endosomal membrane budding and abscission, as well as exosomal cargo selection via interaction with syndecan [23]. These observations led to a hypothesis implicating ESCRT function in exosomal biogenesis.

Interestingly, recent evidence favors an alternative pathway for sorting exosomal cargo into MVBs in an ESCRT-independent manner, which seems to depend on raft-based microdomains for the lateral segregation of cargo within the endosomal membrane. These microdomains are thought to be highly enriched in sphingomyelinases, from which ceramides can be formed by hydrolytic removal of the phosphocholine moiety [24]. Ceramides are known to induce lateral phase separation and coalescence of microdomains in model membranes. Moreover, the cone-shaped structure of ceramide might cause spontaneous negative curvature of the endosomal membrane, thereby promoting domain-induced budding. Consequently, this ceramide-dependent mechanism emphasizes a key role of exosomal lipids in exosome biogenesis [25]. Proteins, such as tetraspanins, also participate in exosome biogenesis and protein loading. Tetraspanin-enriched microdomains (TEMs) are ubiquitous specialized membrane platforms for compartmentalization of receptors and signaling proteins in the plasma membrane [26]. It has been shown that TEMs together with tetraspanin CD81 play a key role in sorting target receptors and intracellular components toward exosomes [27]. Apparently, several specialized mechanisms exist to ensure the specific sorting of bioactive molecules into exosomes, either the ESCRT-dependent or -independent mechanism (involved tetraspanins and lipids), may act variously depending on the origin of the cell type.

In addition to exosomes, other types of membrane vesicles produced by cells include plasma membrane-budded microvesicles (MVs) and apoptotic bodies. MVs are heterogeneous populations of membrane vesicles generated by outward budding from the plasma membrane. They are $100-1000 \mathrm{~nm}$ in size with variable shapes, and are predominately characterized as products of platelets, endothelial cells (ECs), and red blood cells. The density of MVs has been reported to be between 1.25 and $1.30 \mathrm{~g} /$ $\mathrm{mL}$ [28]. Apoptotic bodies are exclusively released from the plasma membrane during the late stage of apoptosis, range in size from 1 to $5 \mathrm{~mm}$, comparable to that of platelets, and contain several intracellular fragments, cellular organelles, membranes, and cytosolic contents. Apoptotic bodies are closed structures with a higher sucrose gradient density than MVs, ranging from 1.18 to $1.28 \mathrm{~g} /$ $\mathrm{mL}$ [29]. The features and characteristics of these cellderived MV types are listed in Table 1. Finally, the comparatively smaller size and unified shape allow exosomes to successfully escape clearance by the mononuclear phagocyte system, not only prolonging their circulation time, but also implying their superiority in cell-cell communication.

\section{The complex architecture of exosomes}

Exosomes have been regarded as mini version of the parental cell, for the complex architecture of exosomes in terms of specially sorted proteins, lipids, nucleic acids, and respective content that highly dependent on the status quo of the cell type of origin. A large variety of constitutive elements have been identified in 


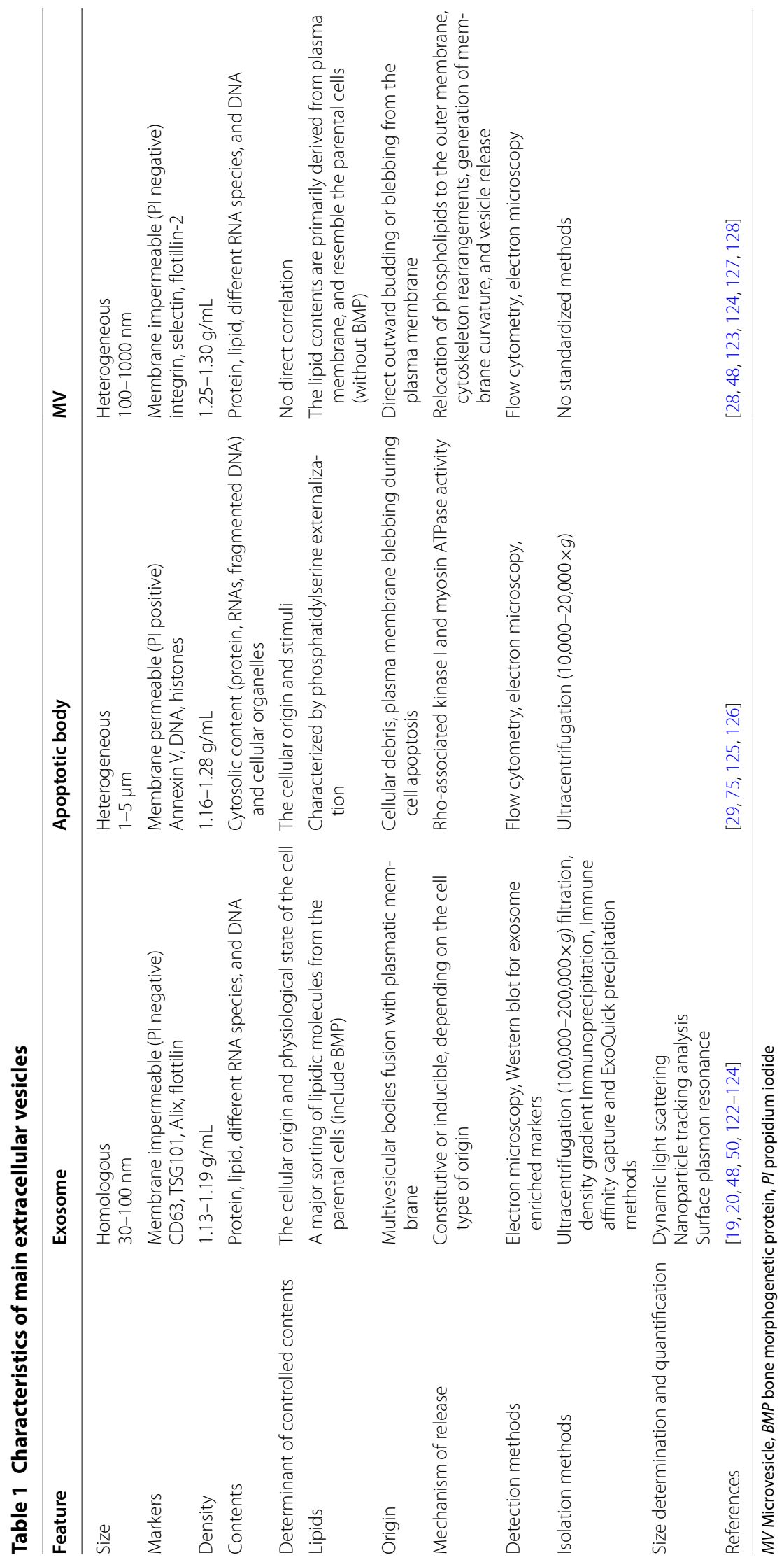


exosomes from different cell types, including approximately 4400 proteins, 194 lipids, 1639 mRNAs, and 764 miRNAs, which illustrate their complexity and potential functional diversity [30, 31]. Typically, exosomes are highly enriched in proteins with various functions, such as tetraspanins (CD9, CD63, CD81, CD82), which take part in cell penetration, invasion, and fusion events; heat shock proteins (HSP70, HSP90), as part of the stress response that are involved in antigen binding and presentation; MVB formation proteins that are involved in exosome release (Alix, TSG101); as well as proteins responsible for membrane transport and fusion (annexins and Rab) [32]. Among these proteins, certain members participate in exosome biogenesis (Alix, flotillin, and TSG101), rendering exosomes distinct from the ectosomes released upon plasma membrane shedding, while others specifically enriched in exosomes are widely used as exosomal marker proteins (e.g. TSG101, HSP70, CD81, and CD63). A detailed summary of protein components found in exosomes is shown in Table 2.
Aside from selected proteins, exosomes also contain different patterns of RNAs that can be incorporated into recipient cells. RNA sequencing analysis showed that microRNAs (miRs) were the most abundant in human plasma derived exosomal RNA species, making up over $42.32 \%$ of all raw reads and $76.20 \%$ of all mappable reads [33]. Other RNA species including ribosomal RNA (9.16\% of all mappable counts), long non-coding RNA (3.36\%), piwi-interacting RNA (1.31\%), transfer RNA (1.24\%), small nuclear RNA $(0.18 \%)$, and small nucleolar RNA (0.01\%). Once miRs are packed into exosomes, they can undergo unidirectional transfer between cells, resulting in the establishment of an intercellular trafficking network, which, in turn, elicits transient or persistent phenotypic changes of recipient cells [8]. MiRs, such as miR-214, miR-29a, miR-1, miR-126, and miR-320, which participate in angiogenesis, hematopoiesis, exocytosis, and tumorigenesis, have already been reported in exosome-based cell to cell communication [34]. Interestingly, besides miRs, long RNA species, especially long non-coding RNAs (lncRNAs) and circular RNAs

Table 2 Common protein components of exosomes

\begin{tabular}{|c|c|}
\hline Protein category and description & Examples \\
\hline Tetraspanins & CD9, CD63, CD81, CD82, CD37, CD53 \\
\hline Heat shock proteins (HSP) & HSP90, HSP70, HSP27, HSP60 \\
\hline Cell adhesion & Integrins, Lactadherin, Intercellular Adhesion Molecule 1 \\
\hline Antigen presentation & Human leukocyte antigen class I and II/peptide complexes \\
\hline Multivesicular body Biogenesis & Tsg101, Alix, Vps, Rab proteins \\
\hline Membrane transport & Lysosomal-associated membrane protein 1/2, CD13, PG regulatory-like protein \\
\hline Signaling proteins & $\begin{array}{l}\text { GTPase HRas, Ras-related protein, furloss, extracellular signal-regulated kinase, Src } \\
\text { homology } 2 \text { domain phosphatase, GDP dissociation inhibitor, Syntenin-1, 14-3-3 } \\
\text { Proteins, Transforming protein RhoA }\end{array}$ \\
\hline Cytoskeleton components & Actins, Cofilin-1, Moesin, Myosin, Tubulins, Erzin, Radixin, Vimentin \\
\hline Transcription and protein synthesis & Histone1, 2, 3, Ribosomal proteins, Ubiquitin, major vault protein, Complement factor 3 \\
\hline Metabolic enzymes & $\begin{array}{l}\text { Fatty acid synthase } \\
\text { Glyceraldehyde-3-phosphate dehydrogenase } \\
\text { Phosphoglycerate kinase } 1 \\
\text { Phosphoglycerate mutase } 1 \\
\text { Pyruvate kinase isozymes M1/M2 } \\
\text { ATP citrate lyase } \\
\text { ATPase } \\
\text { Glucose-6-phosphate isomerase } \\
\text { Peroxiredoxin } 1 \\
\text { Aspartate aminotransferase } \\
\text { Aldehyde reductase }\end{array}$ \\
\hline Trafficking and membrane fusion & $\begin{array}{l}\text { Ras-related protein } 5,7 \\
\text { Annexins I, II, IV, V, VI } \\
\text { Synaptosomal-associated protein } \\
\text { Dynamin, Syntaxin-3 }\end{array}$ \\
\hline Antiapoptosis & Alix, Thioredoxine, Peroxidase \\
\hline Growth factors and cytokine & Tumor Necrosis Factor (TNF)-a, TNF Receptors, Transforming growth factor- $\beta$ \\
\hline Death receptors & FasL, TNF-related apoptosis inducing ligand \\
\hline Iron transport & Transferrin receptor \\
\hline References & {$[18,99,129,130]$} \\
\hline
\end{tabular}


(circRNAs) have recently been reported to be existed in exosomes, and impact a variety of biological processes including the development of cancer [35]. They may function together to transduct cell signals so that local cellular microenvironments will be altered or maintained. Early in 2013, Kogure and his group identified several dramatically altered lncRNAs in human hepatocellular cancer (HCC) cell-derived exosomes [36]. Among them, the novel lncRNA TUC339 was the most highly significantly expressed one, which was functionally implicated in modulating tumor cell growth and adhesion. Thus, they prompted that exosomes-mediated transfer of intercellular functionally active lncRNA as a mechanism of intercellular signaling in HCC. Later, Alice et al. reported that lncRNA H19 could be packaged inside $\mathrm{CD} 90^{+} \mathrm{Huh} 7$ cells-derived exosomes, and be delivered to endothelial cells (ECs), influencing ECs in a pro-metastatic way via the exosome-mediated vascular endothelial growth factor (VEGF) increase [37]. These studies indicate that exosome-mediated transfer of lncRNA is an important mechanism existed in tumor development, and play a crucial role in regulation of the tumor microenvironment via influencing major cellular pathways. Other lncRNAs transmitted by exosomes include lncRNA CRNDE-h in colorectal cancer [38], lncARSR in sunitinib resistance of renal cancer [39], IncRNA Hotair in rheumatoid arthritis [40], lincRNA-p21 and ncRNA-CCND1 in bleomycin-induced DNA damage [41]. CircRNAs were demonstrated high stability, and were not susceptible to exonuclease cleavage, which proposed a possible tumor diagnostic marker. In 2015, Li et al. identified existence of circRNAs in exosomes through RNA sequencing analyses of hepatic MHCC-LM3 cancer cells and cell-derived exosomes [42]. In a comparison of healthy donors and colorectal cancer patients, 67 circRNAs were missing and 257 new circRNA species were detected in cancer patients. Further overexpression of miR-7 in HEK293T cells and MCF-7 cells showed significant downregulation of circRNA CDR1as in exosomes, suggesting that the process of circRNAs entering exosomes may be regulated by intracellular miRs. In a recent study, Exosomal circRNA_100284 derived from arsenite-transformed cells, has been reported to promote malignant transformation of human hepatic cells, via regulation of EZH2 by miR217 [43].

The bioactivity of exosomes exists not only in their proteins and nucleic acids, but also in their lipid components. Generally, exosomes are enriched in phosphatidylserine (PS), phosphatidic acid, cholesterol, sphingomyelin (SM), arachidonic acid and other fatty acids, prostaglandins, and leukotrienes, which account for their stability and structural rigidity (listed in Table 3). Moreover, exosomes also have some functional lipolytic enzymes, which can produce units of various bioactive lipids autonomously. These exosomal bioactive lipids may be internalized into recipient cells, concentrating lipid mediators within the endosomes. Evidence has revealed that accumulation of prostaglandins and fatty acids brought by exosomes during $1 \mathrm{~h}$ can result in micromolar concentrations for prostaglandins, and millimolar concentrations for fatty acids, which are enough to trigger prostaglandin-dependent biological responses [44]. Meanwhile, exosomal lipids may interact with lipid transfer proteins in recipient cytosolic, such as fatty acid binding proteins (FABPs), or receptors such as PPARg for the 15dPGJ2, for conformation of the cytosolic complex AA/ FABP/PPARg [45], which will be further addressed to the nucleus. As a result, the exosome derived 15d-PGJ2

Table 3 Lipid-related enzymes and bioactive lipids in exosomes

\begin{tabular}{lll}
\hline lipid category and description & Lipid related enzymes & Functional effects \\
\hline LTA4, LTB4, LTC4 & LTA4 hydrolase, LTC4 synthase & Triggering polymorphonuclear [131] leukocyte migration \\
PGE2, 15d-PGJ2 & COX-1, COX-2 & Immunosuppression, [44] PPARY ligand \\
PGE2 & PGE synthase & Inflammation [4] \\
PA & PLD2, DGK & Increasing exosome production [132, 133] \\
AA, LPC & CPLA2, iPLA2 & Accounting for the membrane curvature [44] \\
/ & SPLA2 IIA, SPLA2V & Prostaglandin biosynthesis [44] \\
Ceramides & nSMase2 & Sorting cargo into MVBs [134] \\
Cholesterol & $/$ & Regulating exosome secretion [135] \\
BMP & $/$ & MVB formation [135] and subsequent ILV biogenesis [136] \\
PS & $/$ & Being involved in exosome fate [13, 122] \\
SM & $/$ & Triggering calcium influx [135]
\end{tabular}

LA4, LTB4, LTC4 Leukotriene; COX-1, COX-2 cyclooxygenases; PGE2, 15d-PGJ2 prostaglandins; PLD2 phospholipase D2; DGK diglyceride kinase; PA phosphatidic acid; PLA2 phospholipases A2; $C P L A 2$ calcium-dependent phospholipases A2; iPLA2 calcium-independent phospholipases $A 2 ; A A$ arachidonic acid; $L P C$ lysophosphatidylcholine; SPLA2 IIA;V secreted phospholipases A2 IIA and V; nSMase2 neutral sphingomyelinase 2; BMP Bis(monoacylglycero)phosphate, also called LBPA; PS phosphatidylserine; SM sphingomyelin 
and PGE2 may provide a natural way to supply intracellular PGE2. The endosomal AA brought by exosomes can be delivered to the PGE synthase and COXs present in endoplasmic reticulum for an additional PGE2 synthesis. Similarly, the unsaturated 22:6 fatty acid DHA released from exosomes can potentially be addressed to the microsomal antioestrogen binding site in the recipient endoplasmic reticulum [46] and inhibit the activity of the cholesterol epoxide hydrolase which cleaves the cholesterol 5,6 epoxide into cholestanetriol [47]. Since exosomes can be released and taken up by target cells to modulate cell lipid metabolism, exosome-mediated intercellular lipid exchange should be taken into account in the pathogenesis of cholesterol-related storage disease, such as atherosclerosis. Internalization of $\mathrm{T}$ cell-derived exosomes by monocytes via the PS receptor has been shown to effectively facilitate cholesterol accumulation into lipid droplets, implying a role of exosomes in atherosclerosis development [20]. Since exosomes have been shown to play a role in lipid-related pathologies, the lipid content of exosomes may act as another molecular signature for disease diagnosis and prognosis, in addition to protein and RNA biomarkers.

\section{Exosome-mediated intercellular communication}

Traditionally, cells communicate with neighboring cells through direct cell-cell contact including gap junctions, cell surface protein/protein interactions, while communicating with distant cells through secreted soluble factors, such as hormones and cytokines, to facilitate signal propagation [48]. Moreover, electrical and chemical signals (e.g. nucleotides, lipids, and short peptides) are also involved for communication [49]. Interestingly, it is now recognized that exosomes with a cell-specific cargo of proteins, lipids, and nucleic acids may act as a novel intercellular communication mechanism. This concept is based on the observation that exosomes released from parental cells may interact with target cells, leading to the subsequent influence of target cell behavior and phenotype features [50]. The success of exosomal biological applications is highly dependent on effective delivery of genetic materials, which can be achieved via receptor-ligand interactions, direct fusion of membranes, or internalization via endocytosis [51]. Once internalized, exosomes may fuse with the limiting membrane of endosomes, resulting in the horizontal genetic transfer of their content to the cytoplasm of target cells. The bioactive molecules contained in exosomes have been shown to impact target cells via the following mechanisms: (1) direct stimulation of target cells via surface-bound ligands; (2) transfer of activated receptors to recipient cells; and (3) epigenetic reprogramming of recipient cells via delivery of functional proteins, lipids, and RNAs [52] (Fig. 1). As a result, parental cells can communicate with specific proximal or distal target cells through exosome amplification.

In immune system, exosomes have an important function in immunoregulation, including antigen presentation, immune activation, immune suppression, and immune tolerance via exosome-mediated intercellular communication. Exosomes derived from $\mathrm{CD}^{+} \mathrm{T}$ cells and $\mathrm{CD} 8^{+} \mathrm{T}$ cells can bind to dendritic cells (DCs) through peptide/major histocompatibility complex MHC/TCR and ICAM-1/LFA-1 interactions, which lead to the apoptosis of DCs and thus mediate the DCmediated $\mathrm{T}$ cell silence in antigen-specific way [53]. Exosomes secreted by regulatory $\mathrm{T}$ cells contain Let-7b, Let-7d, and microRNA-155, which are able to inhibit Th1 immune response and mediate immune suppression [54]. In addition, CD73-expressing Treg-derived exosomes can produce adenosine which may further inhibit the activation and proliferation of $\mathrm{CD}^{+} \mathrm{T}$ cells $[55,56]$. Meanwhile, B lymphoblast-derived exosomes have also been shown to induce human and mouse-antigen specific $\mathrm{T}$ cell activation, for the presence of $\mathrm{MHC}$-peptide complexes, and even co-stimulatory molecules on them [57]. DCs are professional antigen presenting cells with the unique capacity to induce primary and secondary immune responses. It has been reported that exosomes derived from DCs pulsed with tumor peptide can eradicate or suppress growth of established murine tumors via presentation of class II-peptide complexes to naive T lymphocytes and the priming of specific cytotoxic T lymphocytes in vivo [58].

Mesenchymal stem cells (MSCs) derived exosomes are prompted to be the main effects on wound healing. The therapeutic capacity of MSC-'exosomes' derived from different organs, have been tested in various disease models, demonstrating a similar or even superior functional capacity to MSCs themselves, such as reducing myocardial infarction size [59, 60], preventing adverse remodeling after myocardial ischemia/reperfusion injury [61], providing therapeutic effects in cutaneous wound healing [62], acute kidney injury [63], hepatic injury $[64,65]$, neonatal lung injury [66], promoting survival of retinal ganglion cells in optical nerve crush [67], ameliorating retinal laser injury [68] and orchestrating neurological protection by the transfer of miRs [69].

Surprisingly, in contrast with wide spread cell origin, exosomes do not randomly interact with any recipient cell that happens to be in the vicinity. They may display distinct tissue/cell homing, probably on account of their high expression levels of adhesion molecules, such as integrins and tetraspanins, and their potential target capability [70]. Hence, the selective transmission of 


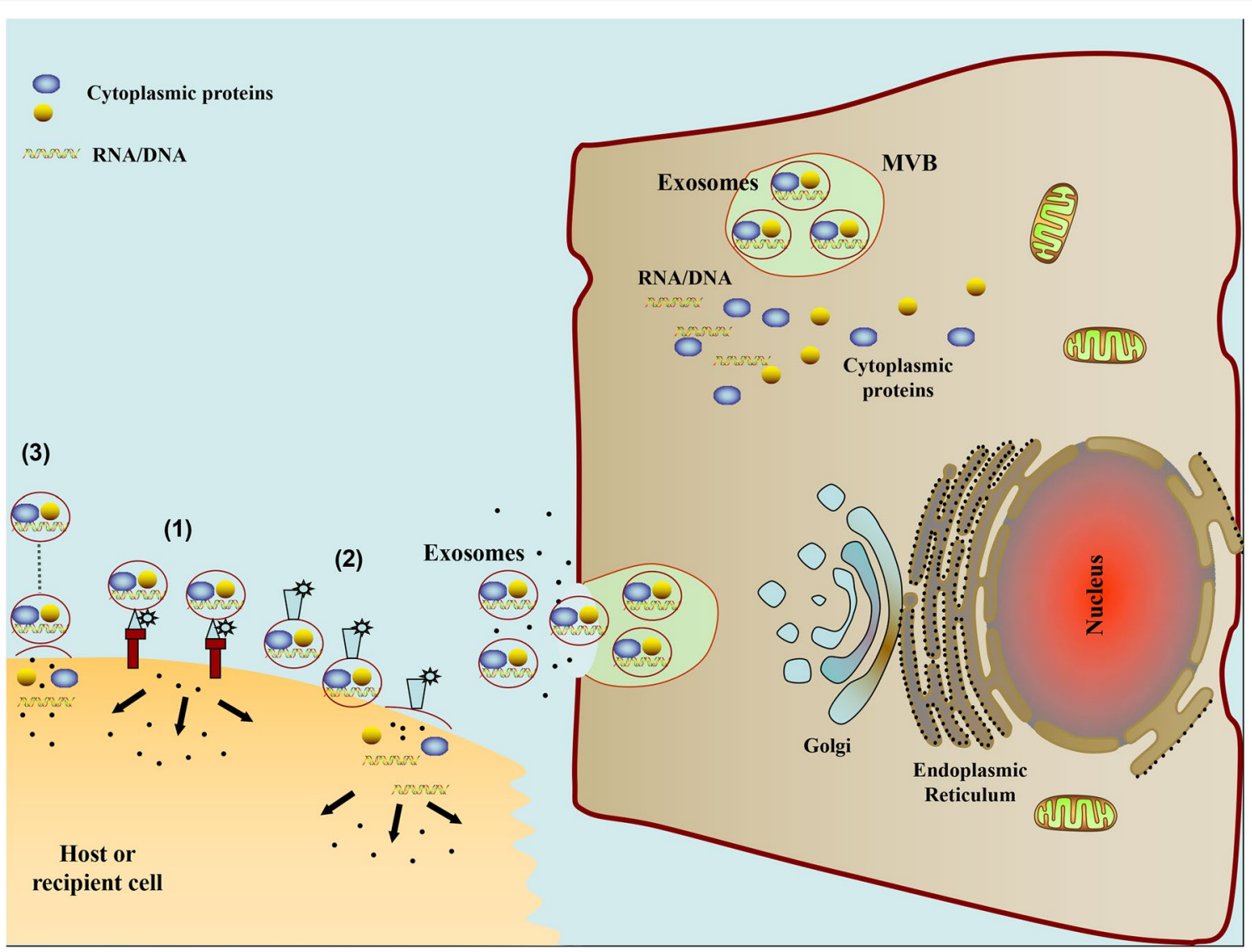

Fig. 1 The schematic diagram of pathways involved in exosome mediated cell-to-cell communication. (1) Exosomes signal recipient cells via direct surface-bound ligands. (2) Exosomes transfer activated receptors to recipient cells. (3) Exosomes may epigenetically reprogram recipient cells via delivery of functional proteins, lipids, and RNAs

exosomal genetic information makes them attractive candidates for the diagnosis and treatment of diseases.

\section{Methods for exosome purification}

Typically, exosomes are characterized by size, morphology, flotation density, and the presence of marker proteins, such as Alix, TSG101, flotillin 1, HSP70, and CD9. Different techniques for isolation of exosomes have been suggested. Generally, exosomes can be isolated from conditioned cell culture media or bodily fluids by differential centrifugation [71], size exclusion chromatography [72], immune affinity capture [73], commercially available kits, or microfluidic technologies. Each approach has its advantages and disadvantages, and may be dictated by the sample source and intended use of exosomes.

Current dogma states that ultracentrifugation at high speeds is the best method to purify exosomes. An elegant study by Webber has shown that using an ultracentrifuge method on a sucrose cushion was able to obtain a highly pure exosomal fraction [74]. However, this was confirmed only valid for exosomes purified from cell culture media, but not the urine and serum with complex mixture of many components, for possible co-sedimentation of protein aggregates and non-specifically bound proteins. Filtration through a series of filters down to $100 \mathrm{~nm}$ pore size followed by centrifugation is an efficient way to collect exosomes away from smaller protein contaminants, although yielding relatively high protein content, still risks impurity because of the fragmentation of larger microparticles into smaller vesicles under filtration pressure [75]. An immunoaffinity pull-down method with the use of antibody-loaded magnetic cell beads can also be performed to selectively enrich exosomes, which is regarded as having the advantage of specificity, but yields are often low [76]. As a result, the most generally accepted and widely used method for purifying exosomes from culture media is to use a well-defined series of serial centrifugation steps that remove cells and microvesicles, followed by concentration via ultracentrifugation and subsequent density gradient purification. However, it is time-consuming, labor-intensive, and in need with expensive equipments. In recent years, several 
commercially available kits have been emerged to enrich exosomes, including ExoQuick (System Bioscience) [77], the Total Exosome Isolation kit (Invitrogen) [78], Exospin (Cell Guidance System) [79]. They are primarily sizebased precipitation approaches with greatly shortening operation time less than $2 \mathrm{~h}$, and have been proven to be efficient, reliable and reproducible when compared with other methods.

However, challenges exist not just in exosome isolation, but rather in rapid and accurate quantification of exosomes with minimal sample preparation, to allow detection of tiny pathological changes of disease. Finally, dynamic light scattering [80] and nanoparticle tracking analysis [81], the alternative methods relying on direct particle counting, have been more recently developed. Despite the rapid, reliable, semi-quantification capabilities of both approaches, a weakness of each is their inability to specifically identify exosomes, partly through particles of a given size. Notably, in recent years, surface plasmon resonance in combination with antibody microarrays specific to exosome membrane proteins of extracellular domains was utilized to quantitatively detect and characterize tumor-derived exosomes without enrichment or purification, which provides an easy, efficient, and novel method for the detection and monitoring of exosomes, thus creating an avenue to advance diagnostic applications of exosomes [82]. The advantage and disadvantage of various methods have been summarized in Table 4.

Of note, the lack of techniques to rapidly isolate, purify, quantitate, and identify exosomes are main drawbacks hampering the clinical use of exosomes. Although recently established technologies may be able to mitigate these drawbacks, additional challenges include the reproducibility and consistency of the product lots, and inadequate quality control and standardization across study groups. Therefore, much more researches are needed for robust validation of these methods to be successfully implemented in clinical diagnosis.

\section{Exosomes in diagnostics}

Over the past few years, exosomes have been discovered in almost all body fluids, including blood, urine [83], saliva [84], breast milk [85], cerebrospinal fluid [86], semen [87], amniotic fluid [88], and ascites [89]. These exosomes with specific profile of miRs, proteins, and lipids can mirror the cellular origin and its physiological state, as a "fingerprint" or a "signature" of the donor cell. Therefore, exosomes and their cell- or condition-specific cargos may better reflect the cellular processes and be used as biomarkers of various diseases.

For example, serum level of exosomal miR-21 has been found to robustly distinguish patients with esophageal squamous cell cancer from patients who have benign diseases [90]. Moreover, it was also found to be significantly higher in patients with HCC than those with chronic hepatitis B or healthy volunteers as well [91]. Furthermore, Machida et al. investigated the diagnostic value of salivary exosomes, and found that their cargos of miR-1246 and miR-4644 were significantly higher in cancer patients with an increased area under the curve of 0.833 , and have the potential for clinical diagnosis of pancreatobiliary tract cancer [92]. In an investigation of bovine milk with bacterial infection, Sun et al. compared miR expression profile of milk exosomes before and after intramammary infection, and found that exosomal btamiR-142-5p, and -223 were significantly up-regulated in response to infection, thus provide a potential for early detection of bacterial infection of the mammary gland [93]. Moreover, exosomal RNAs from amniotic fluid can be used for CD24 Ala/Val SNP (rs52812045) genotyping, which is associated with faster progression of autoimmune diseases. Other than exosmal miR, the analysis of urinary exosome also provide protein biomarkers for kidney injury, such as Fetuin-A [94], aquapotin-1 [95], cyclic AMP-dependent transcription factor-3 [96], Wilms' tumor-1 [97]. Urinary exosomes isolated from prostate cancer patients were even found to contain cancer signatures, e.g. prostate specific antigen, prostate cancer gene 3 [98].

Although the biological fluids are relatively easy to be acquired, and are rich in exosomes, the actual use of exosomal contents (proteins or miRs) as biomarkers has not yet been put into effect in clinical practice. Undoubtedly, the emergence of exosome-based molecular diagnostic tests will herald a new chapter in clinical diagnosis.

\section{Exosomes as drug delivery vehicles}

Exosomes are nanoscale membrane vesicles with the exceptional ability to target specific cells or tissues. They may mediate a horizontal transfer of genetic material via interaction of surface adhesion proteins, resulting in modified biological activities of recipient cells. Besides, exosomes can be obtained from patients' tissues or body fluids with excellent host bio- distribution and biocompatibility, which allows for diminished clearance by the mononuclear phagocyte system [99]. Thus, the issue of immunogenicity can be circumvented, and incorporated therapeutic agents can be delivered without the rapid clearance and toxicity. In recent years, an increasing number of studies have revealed that, in addition to being used as therapeutic entities themselves, exosomes could be regarded as attractive biological vesicles for the efficient delivery of biological therapeutics across different biological barriers to target cells [100-103]. 


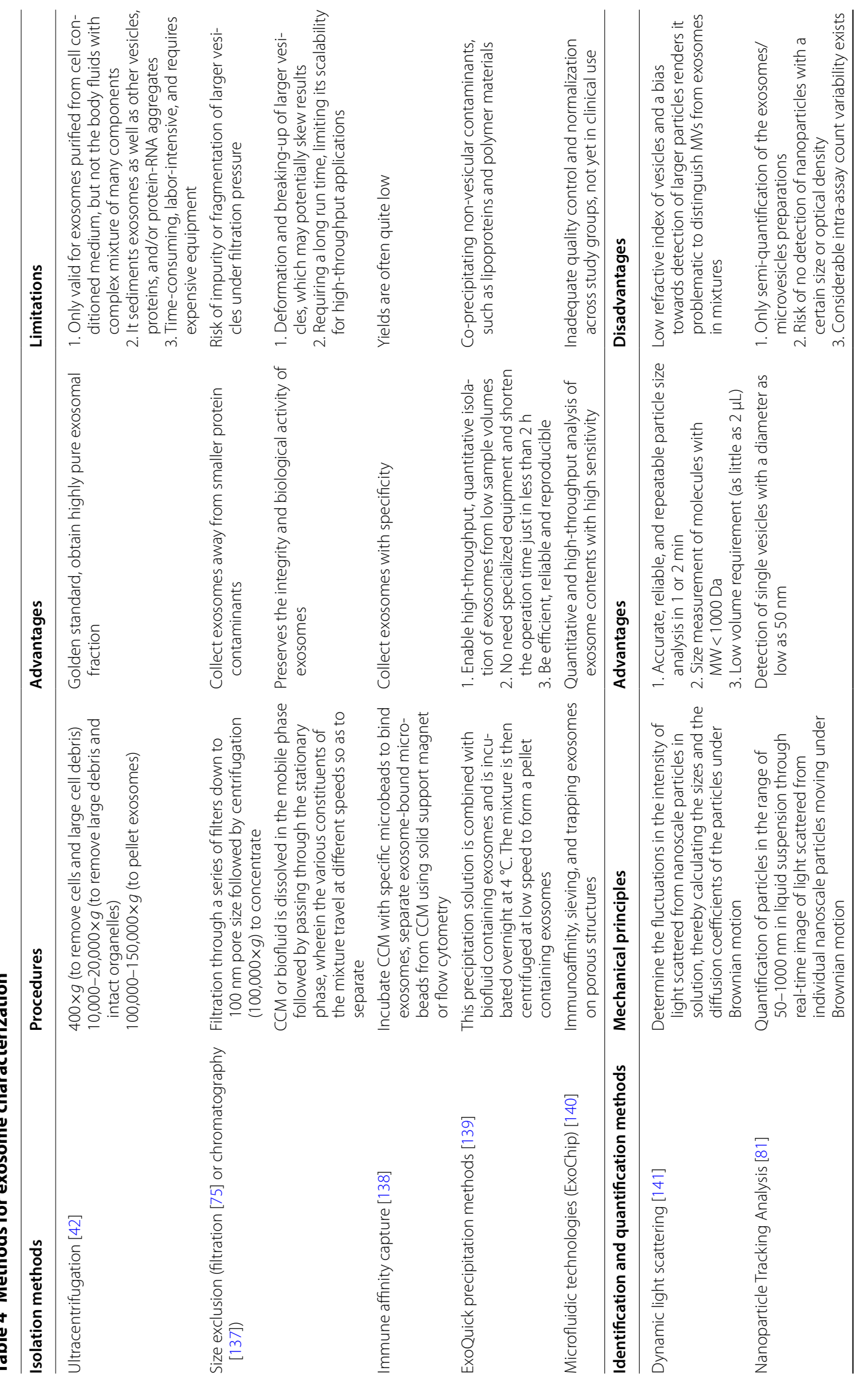




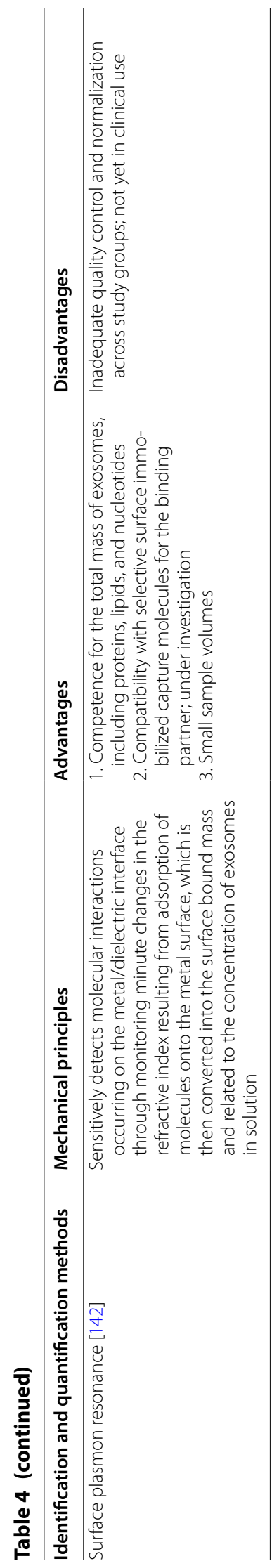


Generally, a variety of therapeutic material, such as short interfering-RNA (siRNA), antagomirs, recombinant proteins, and anti-inflammatory drugs, can be encapsulated for exosome-mediated delivery via several delivery approaches, including: (1) Isolation of exosomes from donor cells ex vivo, and incorporated therapeutic agents into exosomes; (2) Encapsulation of donor cells with the therapeutic agent, which can be sorted into exosomes while exosomal formation; (3) Transfection of donor cells with the drug-encoding DNA, which can be expressed and sorted into exosomes [104]. Each approach has its advantage and limitation (Table 5), primarily depending on the unique characteristics of exosomes, the specific type of therapeutic agent, and site of disease. These artificial exosomes then are capable of delivering their cargos across the blood-brain barrier and confer an active biological effect exactly on target cells.

In one of the first reports, peripheral blood exosomes incorporated with exogenous siRNAs were used for efficient silencing of the target MAPK gene in monocytes and lymphocytes [105]. In another study, Didiot et al. showed that exosomes can be harnessed to deliver siRNAs targeting Huntingtin mRNA to mouse primary cortical neurons, resulting in statistically significant bilateral silencing of Huntingtin mRNA and protein, and consequent therapy of Huntington's disease [106]. Similarly, Yang et al. reported that brain endothelial cell-derived exosomes could deliver VEGF-siRNA across the bloodbrain barrier in zebrafish and decrease the fluorescence intensity of labeled cancer cells [107]. Although almost all types of cells can release exosomes, the quantities of exosomes are relatively low, and the purification procedure is difficult. To deal with this problem, Jang et al. produced bioinspired exosome-mimetic nanovesicles through the breakdown of monocytes or macrophages. Similar characteristics with exosomes were maintained, but 100-fold higher production yield can be observed [108]. Experiments in mice revealed that these chemotherapeutic-loaded nanovesicles are capable of trafficking to tumor tissue and reduce tumor growth without adverse effects.

MSCs are multipotent cells with anti-inflammatory and/or immunosuppressive properties, and emerged as therapeutic agents in many diseases. In recent years, increasing evidences have revealed that the regenerative potential of MSCs are primarily mediated via paracrine factors, especially extracellular vesicles (EVs), including exosomes $[109,110]$. Thus, extensive researches are currently underway for the use of MSCs-derived EVs as effective cell-free therapy. Pascucci et al. showed that MSCs loaded with PTX exhibited strong anti-tumor activity via production of a significant amount of PTXloaded exosomes. These exosomes could package and deliver active drugs to human pancreatic cells, inducing a dose-dependent inhibition of cell proliferation, as well as $50 \%$ tumor growth in vivo [100]. Moreover, Shimbo et al. reported that synthetic miR-143 introduced into MSCs could be released and enveloped into exosomes. These exosome-derived miR-143 was functional and caused significant reduction of osteosarcoma cells migration [111].

Another therapeutic avenue involves the genetic modification of donor cells to product exosomes contained the encoded therapeutic proteins, as well as DNA or mRNA. Exosomes released from genetically modified macrophages that were transfected with a plasmid DNA (pDNA) encoding a potent antioxidant enzyme, catalase, could result in successful gene therapy of Parkinson's disease. These genetically modified macrophages derived exosomes were enveloped with catalase genetic material, including pDNA, mRNA, active catalase, and NF- $\mathrm{kB}$, a transcription factor. They were capable of efficiently transferring their contents to contiguous neurons resulting in de novo protein synthesis in target cells. Notably, the transfected brain tissue showed month-long expression levels of catalase, and a substantial (over 40 days) and profound anti-inflammatory and neuroprotective effects in mice with neuroinflammation [101]. These studies cooperatively demonstrated that exosomes could be used as more efficient delivery vehicles to direct specific targeting of new therapeutics without immunogenicity and adverse effects.

In recent years, exosomes derived from dendritic cells (Dex) pulsed with tumor peptides were actively investigated as clinical cell-free cancer vaccines [112]. Dex was found to possess molecules necessary for antigen presentation, such as MHC class I, MHC class II, costimulatory adhesion molecules, each of which facilitates the functionality of Dex in vivo [113]. Evidences have revealed that Dex is capable of promoting tumor cell-specific cytolysis and eradicating growth of established murine tumors in a $\mathrm{CD}^{+} \mathrm{T}$ cell-dependent manner. Since 2005, the first Phase I clinical trial using autologous MAGE antigen-loaded Dex had been performed on 15 stage III/IV melanoma patients [114]. One partial response and some other tumor regressions were observed in the absence of toxicity. Later, a phase II clinical trial using the second generation of Dex, exosomes derived from interferon (IFN)- $\gamma$-maturated DCs (IFN- $\gamma$-Dex) pulsed with tumor-associated antigenic peptides, was carried out in patients bearing advanced non-small cell lung cancer [115]. Besse et al. found that IFN- $\gamma$-Dex increased NK cell functions and related antitumor immunity in NKp30-dependent manner, resulting in longer progression-free survival. In order to further improve the efficacy of Dex immunotherapy, engineered Dex was developed to carry tumor 


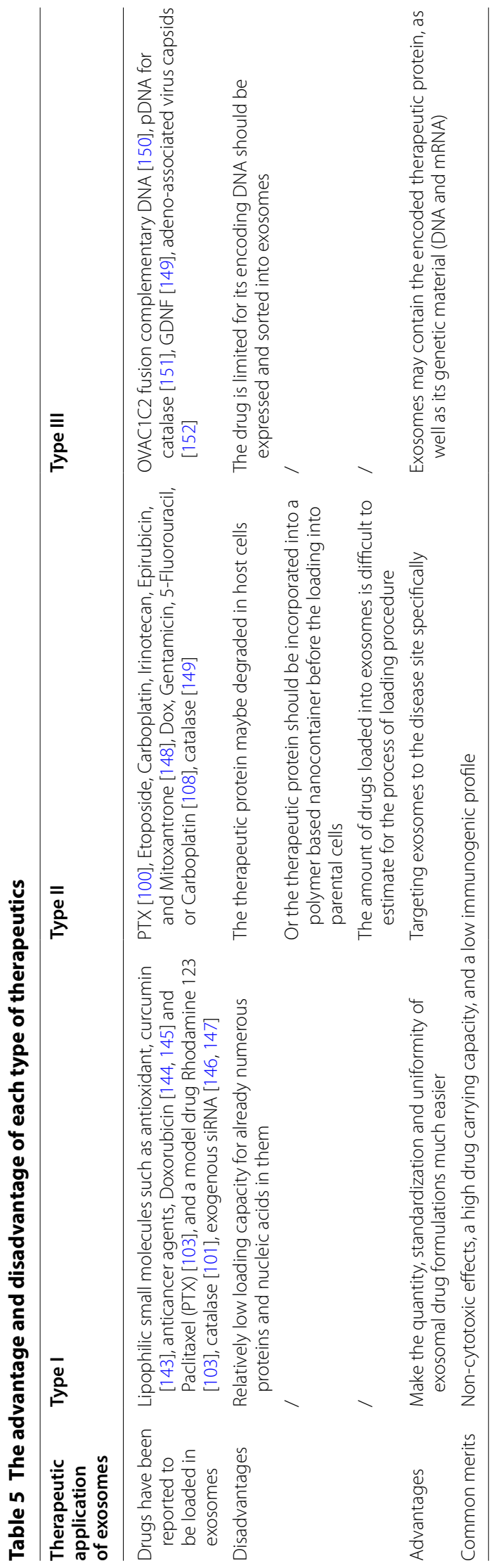


antigen-associated (TAA) proteins or mRNAs, thereby inducing CTL response, leading to inhibition of tumor growth $[116,117]$. Meanwhile, engineered inhibition of some immune checkpoint molecules, such as CTLA-4 or PD-1, in combination with Dex may enhance antitumor $\mathrm{T}$ and $\mathrm{B}$ cell response, improving the outcomes of future clinical trials $[118,119]$.

As a new vaccine strategy for cancer immunotherapy, Dex remain have promising potential for improvements. Future research and clinical trials should focus on how to enhance particular immunostimulatory characteristics: such as greater surface expression of costimulatory molecules, lower expression of immunoregulatory molecules. The choice of TAAs might also be improved to increase the delivered quantity of TAAs to Dex, so as to enhance CTL response. Moreover, engineered Dex has TNF, FasL [120], and TRAIL on its surface may help direct trigger caspase activation and consequent apoptosis of tumor cells [121]. The successful engineered Dex will provide promising therapeutic opportunities for patients with serious cancers.

\section{Conclusions}

In the past few years, an exponential increase studies focused on the biological characteristics of exosomes. The exosomal secretion from various types of cells, existence in almost all kinds of body fluids, and function as mediators of cell-cell communication, which make exosomes play a crucial role in both physiological and pathological processes. Moreover, the capacity of exosomes to envelope with a wide range of content including lipids, RNAs, and proteins to signal specific recipient cells or tissues, makes them a promising diagnostic biomarker and therapeutic tool for treatment of cancers and other pathologies. The clinical application of exosomes is still in its infancy, further investigations will contribute to find out cost- and time-effective nanotechnologies for large-scale production of exosomes. Indeed, exosomes have the capacity of carrying specific therapeutic drugs based on the treatment of corresponding diseases, it is necessary to identify appropriate strategies for further tailoring exosomes as drug delivery vesicles with high drug loading capacity, high specificity, non-cytotoxic effect and low immunogenicity. Furthermore, the isolation, classification, and purification of exosomes need to be standardized to make sure the clinical application of exosomes feasible. Undoubtedly, exosomes represent a promising tool in the field of nanomedicine and may provide the solution to a variety of medical mysteries faced today.

\section{Abbreviations}

MVB: multivesicular body; ILV: intraluminal vesicle; MV: microvesicle; EC: endothelial cells; HSP: heat shock protein; miR: microRNA; IncRNAs: Iong non-coding RNA; circRNA: circular RNAs; HCC: hepatocellular cancer; PS: phosphatidylserine; PA: phosphatidic acid; FABPs: fatty acid binding proteins; VEGF: vascular endothelial growth factor; SM: sphingomyelin; ESCRT: the endosomal sorting complex required for transport; TEM: tetraspanin-enriched microdomains; DCs: dendritic cells; UC: ultracentrifugation; LA: lung adenocarcinoma; ESCC: esophageal squamous cell cancer; CKD: chronic kidney disease; siRNA: short interfering-RNA; MSCs: mesenchymal stem cells; EVs: extracellular vesicles; pDNA: plasmid DNA; Dex: exosomes derived from dendritic cells; TAA : tumor antigen associated.

\section{Authors' contributions}

Each author substantially contributed to the review. YZ: conception and design, drafting the review; $Y L$ and $\mathrm{HL}$ : revising the manuscript; WHD: conception and design, revising it critically for important intellectual content, and final approval of the version to be published. All authors read and approved the final manuscript.

\section{Acknowledgements}

We hope for the understanding of all authors whose important work in the field could not be cited due to word count limitations. We would like to acknowledge my indebtedness to men of important achievements in this field, from whose lectures we benefited greatly.

\section{Competing interests}

The authors declare that they have no competing interests.

\section{Availability of data and materials Not applicable.}

Ethics approval and consent to participate Not applicable.

\section{Publisher's Note}

Springer Nature remains neutral with regard to jurisdictional claims in published maps and institutional affiliations.

Received: 10 May 2018 Accepted: 4 February 2019

Published online: 15 February 2019

\section{References}

1. Johnstone RM, Adam M, Hammond JR, Orr L, Turbide C. Vesicle formation during reticulocyte maturation. Association of plasma membrane activities with released vesicles (exosomes). J Biol Chem. 1987;262(19):9412-20.

2. Simpson RJ, Lim JW, Moritz RL, Mathivanan S. Exosomes: proteomic insights and diagnostic potential. Expert Rev Proteom. 2009;6(3):26783. https://doi.org/10.1586/epr.09.17.

3. Vidal M, Sainte-Marie J, Philippot JR, Bienvenue A. Asymmetric distribution of phospholipids in the membrane of vesicles released during in vitro maturation of guinea pig reticulocytes: evidence precluding a role for "aminophospholipid translocase". J Cell Physiol. 1989;140(3):45562. https://doi.org/10.1002/jcp.1041400308.

4. Valadi H, Ekstrom K, Bossios A, Sjostrand M, Lee JJ, Lotvall JO. Exosomemediated transfer of mRNAs and microRNAs is a novel mechanism of genetic exchange between cells. Nat Cell Biol. 2007;9(6):654-9. https:// doi.org/10.1038/ncb1596.

5. Waldenstrom A, Genneback N, Hellman U, Ronquist G. Cardiomyocyte microvesicles contain DNA/RNA and convey biological messages to target cells. PLoS ONE. 2012;7(4):e34653. https://doi.org/10.1371/journ al.pone.0034653.

6. Greening DW, Gopal SK, Xu R, Simpson RJ, Chen W. Exosomes and their roles in immune regulation and cancer. Semin Cell Dev Biol. 2015;40:72-81. https://doi.org/10.1016/j.semcdb.2015.02.009. 
7. Gangoda L, Boukouris S, Liem M, Kalra H, Mathivanan S. Extracellular vesicles including exosomes are mediators of signal transduction: are they protective or pathogenic? Proteomics. 2015;15(2-3):260-71. https://doi.org/10.1002/pmic.201400234.

8. Mittelbrunn M, Gutierrez-Vazquez C, Villarroya-Beltri C, Gonzalez S, Sanchez-Cabo F, Gonzalez MA, Bernad A, Sanchez-Madrid F. Unidirectional transfer of microRNA-loaded exosomes from T cells to antigenpresenting cells. Nat Commun. 2011;2:282. https://doi.org/10.1038/ ncomms 1285.

9. Lasser C, O'Neil SE, Shelke GV, Sihlbom C, Hansson SF, Gho YS, Lundback B, Lotvall J. Exosomes in the nose induce immune cell trafficking and harbour an altered protein cargo in chronic airway inflammation. J Transl Med. 2016;14(1):181. https://doi.org/10.1186/ s12967-016-0927-4.

10. Gonzalez-Calero L, Martin-Lorenzo M, Alvarez-Llamas G. Exosomes: a potential key target in cardio-renal syndrome. Front Immunol. 2014;5:465. https://doi.org/10.3389/fimmu.2014.00465.

11. Kishore R, Garikipati VN, Gumpert A. Tiny shuttles for information transfer: exosomes in cardiac health and disease. J Cardiovasc Trans Res. 2016;9(3):169-75. https://doi.org/10.1007/s12265-016-9682-4.

12. Howitt J, Hill AF. Exosomes in the pathology of neurodegenerative diseases. J Biol Chem. 2016;291(52):26589-97. https://doi. org/10.1074/jbc.R116.757955.

13. Record M, Poirot M, Silvente-Poirot S. Emerging concepts on the role of exosomes in lipid metabolic diseases. Biochimie. 2014;96:67-74. https://doi.org/10.1016/j.biochi.2013.06.016.

14. Salem KZ, Moschetta M, Sacco A, Imberti L, Rossi G, Ghobrial IM, Manier S, Roccaro AM. Exosomes in tumor angiogenesis. Methods Mol Biol (Clifton, NJ). 2016;1464:25-34. https://doi. org/10.1007/978-1-4939-3999-2_3.

15. Minciacchi VR, Freeman MR, Di Vizio D. Extracellular vesicles in cancer: exosomes, microvesicles and the emerging role of large oncosomes. Semin Cell Dev Biol. 2015;40:41-51. https://doi.org/10.1016/j.semcd b.2015.02.010.

16. Sahu R, Kaushik S, Clement CC, Cannizzo ES, Scharf B, Follenzi A, Potolicchio I, Nieves E, Cuervo AM, Santambrogio L. Microautophagy of cytosolic proteins by late endosomes. Dev Cell. 2011;20(1):131-9. https://doi.org/10.1016/j.devcel.2010.12.003.

17. Record M. Intercellular communication by exosomes in placenta: a possible role in cell fusion? Placenta. 2014;35(5):297-302. https://doi. org/10.1016/j.placenta.2014.02.009.

18. Yellon DM, Davidson SM. Exosomes: nanoparticles involved in cardioprotection? Circ Res. 2014;114(2):325-32. https://doi.org/10.1161/ circresaha.113.300636.

19. Bobrie A, Colombo M, Raposo G, Thery C. Exosome secretion: molecular mechanisms and roles in immune responses. Traffic (Copenhagen, Denmark). 2011;12(12):1659-68. https://doi.org/10.11 11/j.1600-0854.2011.01225.x.

20. Zakharova L, Svetlova M, Fomina AF. T cell exosomes induce cholesterol accumulation in human monocytes via phosphatidylserine receptor. J Cell Physiol. 2007;212(1):174-81. https://doi.org/10.1002/ jcp.21013.

21. Henne WM, Buchkovich NJ, Emr SD. The ESCRT pathway. Dev Cell. 2011;21(1):77-91. https://doi.org/10.1016/j.devcel.2011.05.015.

22. Hurley JH. ESCRTs are everywhere. EMBO J. 2015;34(19):2398-407. https ://doi.org/10.15252/embj.201592484.

23. Villarroya-Beltri C, Baixauli F, Gutierrez-Vazquez C, Sanchez-Madrid F, Mittelbrunn M. Sorting it out: regulation of exosome loading. Semin Cancer Biol. 2014;28:3-13. https://doi.org/10.1016/j.semca ncer.2014.04.009.

24. Airola MV, Hannun YA. Sphingolipid metabolism and neutral sphingomyelinases. Handb Exp Pharmacol. 2013;215:57-76. https://doi. org/10.1007/978-3-7091-1368-4_3.

25. Castro BM, Prieto M, Silva LC. Ceramide: a simple sphingolipid with unique biophysical properties. Prog Lipid Res. 2014;54:53-67. https:// doi.org/10.1016/j.plipres.2014.01.004.

26. Perez-Hernandez D, Gutierrez-Vazquez C, Jorge I, Lopez-Martin S, Ursa A, Sanchez-Madrid F, Vazquez J, Yanez-Mo M. The intracellular interactome of tetraspanin-enriched microdomains reveals their function as sorting machineries toward exosomes. J Biol Chem. 2013;288(17):11649-61. https://doi.org/10.1074/jbc.M112.445304.
27. van den Boorn JG, Dassler J, Coch C, Schlee M, Hartmann G. Exosomes as nucleic acid nanocarriers. Adv Drug Deliv Rev. 2013;65(3):331-5. https://doi.org/10.1016/j.addr.2012.06.011.

28. Muller G, Jung C, Wied S, Biemer-Daub G, Frick W. Transfer of the glycosylphosphatidylinositol-anchored 5'-nucleotidase CD73 from adiposomes into rat adipocytes stimulates lipid synthesis. Br J Pharmacol. 2010;160(4):878-91. https://doi.org/10.1111/j.1476-5381.2010.00724.X.

29. Thery C, Boussac M, Veron P, Ricciardi-Castagnoli P, Raposo G, Garin J, Amigorena S. Proteomic analysis of dendritic cell-derived exosomes: a secreted subcellular compartment distinct from apoptotic vesicles. J Immunol (Baltimore, Md: 1950). 2001;166(12):7309-18.

30. Mathivanan S, Fahner CJ, Reid GE, Simpson RJ. ExoCarta 2012: database of exosomal proteins, RNA and lipids. Nucleic Acids Res. 2012;40(Database issue):D1241-4. https://doi.org/10.1093/nar/gkr828.

31. Kim DK, Kang B, Kim OY, Choi DS, Lee J, Kim SR, Go G, Yoon YJ, Kim JH, Jang SC, Park KS, Choi EJ, Kim KP, Desiderio DM, Kim YK, Lotvall J, Hwang D, Gho YS. EVpedia: an integrated database of high-throughput data for systemic analyses of extracellular vesicles. J Extracell Vesicles. 2013. https://doi.org/10.3402/jev.v2i0.20384.

32. Vlassov AV, Magdaleno S, Setterquist R. Conrad R (2012) Exosomes: current knowledge of their composition, biological functions, and diagnostic and therapeutic potentials. Biochem Biophys Acta. 1820;7:940-8. https://doi.org/10.1016/j.bbagen.2012.03.017.

33. Huang $X$, Yuan T, Tschannen M, Sun Z, Jacob H, Du M, Liang M, Dittmar RL, Liu Y, Liang M, Kohli M, Thibodeau SN, Boardman L, Wang L. Characterization of human plasma-derived exosomal RNAs by deep sequencing. BMC Genom. 2013;14:319. https://doi. org/10.1186/1471-2164-14-319.

34. Waldenstrom $\mathrm{A}$, Ronquist $\mathrm{G}$. Role of exosomes in myocardial remodeling. Circ Res. 2014;114(2):315-24. https://doi.org/10.1161/CIRCR ESAHA.114.300584.

35. Hewson C, Capraro D, Burdach J, Whitaker N, Morris KV. Extracellular vesicle associated long non-coding RNAs functionally enhance cell viability. Non-coding RNA Res. 2016;1 (1):3-11. https://doi.org/10.1016/j. ncrna.2016.06.001.

36. Kogure T, Yan IK, Lin WL, Patel T. Extracellular Vesicle-mediated transfer of a novel long noncoding RNA TUC339: a mechanism of intercellular signaling in human hepatocellular cancer. Genes Cancer. 2013;4(78):261-72. https://doi.org/10.1177/1947601913499020.

37. Conigliaro A, Costa V, Lo Dico A, Saieva L, Buccheri S, Dieli F, Manno M, Raccosta S, Mancone C, Tripodi M, De Leo G, Alessandro R. CD90+ liver cancer cells modulate endothelial cell phenotype through the release of exosomes containing H19 IncRNA. Mol Cancer. 2015;14:155. https:// doi.org/10.1186/s12943-015-0426-X.

38. Liu T, Zhang X, Gao S, Jing F, Yang Y, Du L, Zheng G, Li P, Li C, Wang C. Exosomal long noncoding RNA CRNDE-h as a novel serum-based biomarker for diagnosis and prognosis of colorectal cancer. Oncotarget. 2016;7(51):85551-63. https://doi.org/10.18632/oncotarget.13465.

39. Qu L, Ding J, Chen C, Wu ZJ, Liu B, Gao Y, Chen W, Liu F, Sun W, Li XF, Wang $X$, Wang $Y, X u Z Y$, Gao L, Yang Q, Xu B, Li YM, Fang ZY, Xu ZP, Bao Y, Wu DS, Miao X, Sun HY, Sun YH, Wang HY, Wang LH. Exosome-transmitted IncARSR promotes sunitinib resistance in renal cancer by acting as a competing endogenous RNA. Cancer Cell. 2016;29(5):653-68. https:// doi.org/10.1016/j.ccell.2016.03.004.

40. Song J, Kim D, Han J, Kim Y, Lee M, Jin EJ. PBMC and exosome-derived Hotair is a critical regulator and potent marker for rheumatoid arthritis. Clin Exp Med. 2015;15(1):121-6. https://doi.org/10.1007/s1023 8-013-0271-4

41. Gezer U, Ozgur E, Cetinkaya M, Isin M, Dalay N. Long non-coding RNAs with low expression levels in cells are enriched in secreted exosomes. Cell Biol Int. 2014;38(9):1076-9. https://doi.org/10.1002/cbin.10301.

42. LiY, Zheng Q, Bao C, Li S, Guo W, Zhao J, Chen D, Gu J, He X, Huang S. Circular RNA is enriched and stable in exosomes: a promising biomarker for cancer diagnosis. Cell Res. 2015;25(8):981-4. https://doi. org/10.1038/cr.2015.82.

43. Dai X, Chen C, Yang Q, Xue J, Chen X, Sun B, Luo F, Liu X, Xiao T, Xu H, Sun Q, Zhang A, Liu Q. Exosomal circRNA_100284 from arsenite-transformed cells, via microRNA-217 regulation of $\mathrm{EZH}$, is involved in the malignant transformation of human hepatic cells by accelerating the cell cycle and promoting cell proliferation. Cell Death Dis. 2018;9(5):454. https://doi.org/10.1038/s41419-018-0485-1. 
44. Subra C, Grand D, Laulagnier K, Stella A, Lambeau G, Paillasse M, De Medina P, Monsarrat B, Perret B, Silvente-Poirot S, Poirot M, Record $M$. Exosomes account for vesicle-mediated transcellular transport of activatable phospholipases and prostaglandins. J Lipid Res. 2010;51(8):2105-20. https://doi.org/10.1194/jlr.M003657.

45. Tan NS, Shaw NS, Vinckenbosch N, Liu P, Yasmin R, Desvergne B, Wahli W, Noy N. Selective cooperation between fatty acid binding proteins and peroxisome proliferator-activated receptors in regulating transcription. Mol Cell Biol. 2002;22(14):5114-27.

46. Kedjouar B, de Medina P, Oulad-Abdelghani M, Payre B, Silvente-Poirot S, Favre G, Faye JC, Poirot M. Molecular characterization of the microsomal tamoxifen binding site. J Biol Chem. 2004;279(32):34048-61. https ://doi.org/10.1074/jbc.M405230200.

47. de Medina P, Paillasse MR, Segala G, Khallouki F, Brillouet S, Dalenc F, Courbon F, Record M, Poirot M, Silvente-Poirot S. Importance of cholesterol and oxysterols metabolism in the pharmacology of tamoxifen and other AEBS ligands. Chem Phys Lipid. 2011;164(6):432-7. https://doi. org/10.1016/j.chemphyslip.2011.05.005.

48. Camussi G, Deregibus MC, Bruno S, Cantaluppi V, Biancone L. Exosomes/microvesicles as a mechanism of cell-to-cell communication. Kidney Int. 2010;78(9):838-48. https://doi.org/10.1038/ki.2010.278.

49. Nazimek K, Bryniarski K, Santocki M, Ptak W. Exosomes as mediators of intercellular communication: clinical implications. Pol Arch Med Wewn. 2015;125(5):370-80.

50. Simons M, Raposo G. Exosomes-vesicular carriers for intercellular communication. Curr Opin Cell Biol. 2009;21(4):575-81. https://doi. org/10.1016/j.ceb.2009.03.007.

51. Tian T, Wang Y, Wang H, Zhu Z, Xiao Z. Visualizing of the cellular uptake and intracellular trafficking of exosomes by live-cell microscopy. J Cell Biochem. 2010;111(2):488-96. https://doi.org/10.1002/jcb.22733.

52. Khalyfa A, Gozal D. Exosomal miRNAs as potential biomarkers of cardiovascular risk in children. J Transl Med. 2014;12:162. https://doi. org/10.1186/1479-5876-12-162.

53. Zhang H, Xie Y, Li W, Chibbar R, Xiong S, Xiang J. CD4(+) T cell-released exosomes inhibit CD8(+) cytotoxic T-lymphocyte responses and antitumor immunity. Cell Mol Immunol. 2011;8(1):23-30. https://doi. org/10.1038/cmi.2010.59.

54. Okoye IS, Coomes SM, Pelly VS, Czieso S, Papayannopoulos V, Tolmachova T, Seabra MC, Wilson MS. MicroRNA-containing T-regulatorycell-derived exosomes suppress pathogenic Thelper 1 cells. Immunity. 2014;41(3):503. https://doi.org/10.1016/j.immuni.2014.08.008.

55. Smyth LA, Ratnasothy K, Tsang JY, Boardman D, Warley A, Lechler R, Lombardi G. CD73 expression on extracellular vesicles derived from CD4+ CD25+ Foxp3+ T cells contributes to their regulatory function. Eur J Immunol. 2013;43(9):2430-40. https://doi.org/10.1002/eji.20124 2909.

56. Clayton A, Al-Taei S, Webber J, Mason MD, Tabi Z. Cancer exosomes express CD39 and CD73, which suppress T cells through adenosine production. J Immunol (Baltimore, Md: 1950). 2011;187(2):676-83. https ://doi.org/10.4049/jimmunol.1003884.

57. Raposo G, Nijman HW, Stoorvogel W, Liejendekker R, Harding CV, Melief CJ, Geuze HJ. B lymphocytes secrete antigen-presenting vesicles. J Exp Med. 1996;183(3):1161-72.

58. Zitvogel L, Regnault A, Lozier A, Wolfers J, Flament C, Tenza D, RicciardiCastagnoli P, Raposo G, Amigorena S. Eradication of established murine tumors using a novel cell-free vaccine: dendritic cell-derived exosomes. Nat Med. 1998:4(5):594-600

59. Liu L, Jin X, Hu CF, Li R, Zhou Z, Shen CX. Exosomes derived from mesenchymal stem cells rescue myocardial ischaemia/reperfusion injury by inducing cardiomyocyte autophagy via AMPK and Akt pathways. Cell Physiol Biochem Int J Exp Cell Physiol Biochem Pharmacol. 2017:43(1):52-68. https://doi.org/10.1159/000480317.

60. Lai RC, Arslan F, Lee MM, Sze NS, Choo A, Chen TS, Salto-Tellez M, Timmers L, Lee CN, El Oakley RM, Pasterkamp G, de Kleijn DP, Lim SK. Exosome secreted by MSC reduces myocardial ischemia/reperfusion injury. Stem Cell Res. 2010;4(3):214-22. https://doi.org/10.1016/j. scr.2009.12.003

61. Cui X, He Z, Liang Z, Chen Z, Wang H, Zhang J. Exosomes from adiposederived mesenchymal stem cells protect the myocardium against ischemia/reperfusion injury through wnt/beta-catenin signaling pathway. J Cardiovasc Pharmacol. 2017;70(4):225-31. https://doi. org/10.1097/fic.0000000000000507.

62. Zhang B, Wang M, Gong A, Zhang X, Wu X, Zhu Y, Shi H, Wu L, Zhu W, Qian H, Xu W. HucMSC-exosome mediated-Wnt4 signaling is required for cutaneous wound healing. Stem Cells (Dayton, Ohio). 2015;33(7):2158-68. https://doi.org/10.1002/stem.1771.

63. van Koppen A, Joles JA, van Balkom BW, Lim SK, de Kleijn D, Giles RH, Verhaar MC. Human embryonic mesenchymal stem cell-derived conditioned medium rescues kidney function in rats with established chronic kidney disease. PLoS ONE. 2012;7(6):e38746. https://doi.org/10.1371/ journal.pone.0038746.

64. Tan CY, Lai RC, Wong W, Dan YY, Lim SK, Ho HK. Mesenchymal stem cellderived exosomes promote hepatic regeneration in drug-induced liver injury models. Stem Cell Res Ther. 2014;5(3):76. https://doi.org/10.1186/ scrt465.

65. Jiang W, Tan Y, Cai M, Zhao T, Mao F. Human umbilical cord MSCderived exosomes suppress the development of CCl4-induced liver injury through antioxidant effect. 2018. Article ID: 6079642. https://doi. org/10.1155/2018/6079642.

66. Willis GR, Mitsialis SA, Kourembanas S. "Good things come in small packages": application of exosome-based therapeutics in neonatal lung injury. Pediatr Res. 2018;83(1-2):298-307. https://doi.org/10.1038/ pr.2017.256

67. Mead B, Tomarev S. Bone marrow-derived mesenchymal stem cells-derived exosomes promote survival of retinal ganglion cells through miRNA-Dependent mechanisms. Stem Cells Transl Med. 2017;6(4):1273-85. https://doi.org/10.1002/sctm.16-0428.

68. Yu B, Shao H, Su C, Jiang Y, Chen X, Bai L, Zhang Y, Li Q, Zhang X, Li X. Exosomes derived from MSCs ameliorate retinal laser injury partially by inhibition of MCP-1. Scientific reports. 2016;6:34562. https://doi. org/10.1038/srep34562.

69. Xin H, Li Y, Buller B, Katakowski M, Zhang Y, Wang X, Shang X, Zhang ZG, Chopp M. Exosome-mediated transfer of miR-133b from multipotent mesenchymal stromal cells to neural cells contributes to neurite outgrowth. Stem Cells (Dayton, Ohio). 2012;30(7):1556-64. https://doi. org/10.1002/stem.1129.

70. Zoller M. Tetraspanins: push and pull in suppressing and promoting metastasis. Nat Rev Cancer. 2009;9(1):40-55. https://doi.org/10.1038/ nrc2543.

71. Faught $\mathrm{E}$, Henrickson L, Vijayan MM. Plasma exosomes are enriched in Hsp70 and modulated by stress and cortisol in rainbow trout. J Endocrinol. 2017;232(2):237-46. https://doi.org/10.1530/joe-16-0427.

72. Hong CS, Funk S, Muller L, Boyiadzis M, Whiteside TL. Isolation of biologically active and morphologically intact exosomes from plasma of patients with cancer. J Extracell Vesicles. 2016;5:29289. https://doi. org/10.3402/jev.v5.29289.

73. Zarovni N, Corrado A, Guazzi P, Zocco D, Lari E, Radano G, Muhhina J, Fondelli C, Gavrilova J, Chiesi A. Integrated isolation and quantitative analysis of exosome shuttled proteins and nucleic acids using immunocapture approaches. Methods (San Diego, Calif). 2015;87:46-58. https:// doi.org/10.1016/j.ymeth.2015.05.028.

74. Webber J, Steadman R, Mason MD, Tabi Z, Clayton A. Cancer exosomes trigger fibroblast to myofibroblast differentiation. Can Res. 2010;70(23):9621-30. https://doi.org/10.1158/0008-5472.can-10-1722.

75. Gyorgy B, Szabo TG, Pasztoi M, Pal Z, Misjak P, Aradi B, Laszlo V, Pallinger E, Pap E, Kittel A, Nagy G, Falus A, Buzas El. Membrane vesicles, current state-of-the-art: emerging role of extracellular vesicles. Cell Mol Life Sci CMLS. 2011;68(16):2667-88. https://doi.org/10.1007/s0001 8-011-0689-3.

76. Prunotto M, Farina A, Lane L, Pernin A, Schifferli J, Hochstrasser DF, Lescuyer P, Moll S. Proteomic analysis of podocyte exosome-enriched fraction from normal human urine. J Proteom. 2013;82:193-229. https:// doi.org/10.1016/j.jprot.2013.01.012.

77. de Hoog VC, Timmers L, Schoneveld AH, Wang JW, van de Weg SM, Sze SK, van Keulen JK, Hoes AW, den Ruijter HM, de Kleijn DP, Mosterd A. Serum extracellular vesicle protein levels are associated with acute coronary syndrome. Eur Heart J Acute Cardiovasc Care. 2013;2(1):53-60. https://doi.org/10.1177/2048872612471212.

78. Oksvold MP, Kullmann A, Forfang L, Kierulf B, Li M, Brech A, Vlassov AV, Smeland EB, Neurauter A, Pedersen KW. Expression of B-cell surface antigens in subpopulations of exosomes released from B-cell 
lymphoma cells. Clin Ther. 2014;36(6):847-862.e841. https://doi. org/10.1016/j.clinthera.2014.05.010.

79. Barile L, Lionetti V, Cervio E, Matteucci M, Gherghiceanu M, Popescu LM, Torre T, Siclari F, Moccetti T, Vassalli G. Extracellular vesicles from human cardiac progenitor cells inhibit cardiomyocyte apoptosis and improve cardiac function after myocardial infarction. Cardiovasc Res. 2014;103(4):530-41. https://doi.org/10.1093/cvr/cvu167.

80. Kesimer M, Gupta R. Physical characterization and profiling of airway epithelial derived exosomes using light scattering. Methods (San Diego, Calif). 2015;87:59-63. https://doi.org/10.1016/j.ymeth.2015.03.013.

81. Oosthuyzen W, Sime NE, IVy JR, Turtle EJ, Street JM, Pound J, Bath LE, Webb DJ, Gregory CD, Bailey MA, Dear JW. Quantification of human urinary exosomes by nanoparticle tracking analysis. J Physiol. 2013;591 (Pt 23):5833-42. https://doi.org/10.1113/jphysiol.2013.264069.

82. Zhu L, Wang K, Cui J, Liu H, Bu X, Ma H, Wang W, Gong H, Lausted C, Hood L, Yang G, Hu Z. Label-free quantitative detection of tumorderived exosomes through surface plasmon resonance imaging. Anal Chem. 2014;86(17):8857-64. https://doi.org/10.1021/ac5023056.

83. Street JM, Koritzinsky EH, Glispie DM, Star RA, Yuen PS. Urine exosomes: an emerging trove of biomarkers. Adv Clin Chem. 2017;78:103-22. https://doi.org/10.1016/bs.acc.2016.07.003.

84. Machida T, Tomofuji T, Ekuni D, Maruyama T, Yoneda T, Kawabata Y, Mizuno $\mathrm{H}$, Miyai $\mathrm{H}$, Kunitomo M, Morita M. MicroRNAs in salivary exosome as potential biomarkers of aging. Int J Mol Sci. 2015;16(9):21294-309. https://doi.org/10.3390/ijms160921294.

85. Qin W, Tsukasaki Y, Dasgupta S, Mukhopadhyay N, Ikebe M, Sauter ER. Exosomes in human breast milk promote EMT. Clin Cancer Res. 2016;22(17):4517-24. https://doi.org/10.1158/1078-0432.ccr-16-0135.

86. Yagi Y, Ohkubo T, Kawaji H, Machida A, Miyata H, Goda S, Roy S, Hayashizaki Y, Suzuki H, Yokota T. Next-generation sequencing-based small RNA profiling of cerebrospinal fluid exosomes. Neurosci Lett. 2017;636:4857. https://doi.org/10.1016/j.neulet.2016.10.042.

87. Madison MN, Jones PH, Okeoma CM. Exosomes in human semen restrict HIV-1 transmission by vaginal cells and block intravaginal replication of LP-BM5 murine AIDS virus complex. Virology. 2015;482:189201. https://doi.org/10.1016/j.virol.2015.03.040.

88. Keller S, Rupp C, Stoeck A, Runz S, Fogel M, Lugert S, Hager HD, Abdel-Bakky MS, Gutwein P, Altevogt P. CD24 is a marker of exosomes secreted into urine and amniotic fluid. Kidney Int. 2007;72(9):1095-102. https://doi.org/10.1038/sj.ki.5002486.

89. Peng $\mathrm{P}$, Yan $\mathrm{Y}, \mathrm{Keng} \mathrm{S}$. Exosomes in the ascites of ovarian cancer patients: origin and effects on anti-tumor immunity. Oncol Rep. 2011;25(3):749-62. https://doi.org/10.3892/or.2010.1119.

90. Tanaka Y, Kamohara H, Kinoshita K, Kurashige J, Ishimoto T, Iwatsuki M, Watanabe M, Baba H. Clinical impact of serum exosomal microRNA-21 as a clinical biomarker in human esophageal squamous cell carcinoma. Cancer. 2013;119(6):1159-67. https://doi.org/10.1002/cncr.27895.

91. Wang H, Hou L, Li A, Duan Y, Gao H, Song X. Expression of serum exosomal microRNA-21 in human hepatocellular carcinoma. Biomed Res Int. 2014;2014:864894. https://doi.org/10.1155/2014/864894.

92. Machida T, Tomofuji T, Maruyama T, Yoneda T, Ekuni D, Azuma T, Miyai H, Mizuno H, Kato H, Tsutsumi K, Uchida D, Takaki A, Okada H, Morita M. miR1246 and miR4644 in salivary exosome as potential biomarkers for pancreatobiliary tract cancer. Oncol Rep. 2016;36(4):2375-81. https:// doi.org/10.3892/or.2016.5021.

93. Sun J, Aswath K, Schroeder SG, Lippolis JD, Reinhardt TA, Sonstegard TS. MicroRNA expression profiles of bovine milk exosomes in response to Staphylococcus aureus infection. BMC Genom. 2015;16:806. https://doi. org/10.1186/s12864-015-2044-9.

94. Zhou H, Pisitkun T, Aponte A, Yuen PS, Hoffert JD, Yasuda H, Hu X, Chawla L, Shen RF, Knepper MA, Star RA. Exosomal Fetuin-A identified by proteomics: a novel urinary biomarker for detecting acute kidney injury. Kidney Int. 2006;70(10):1847-57. https://doi.org/10.1038/ sj.ki.5001874.

95. Oshikawa S, Sonoda H, Ikeda M. Aquaporins in urinary extracellular vesicles (exosomes). Int J Mol Sci. 2016. https://doi.org/10.3390/ijms1 7060957.

96. Zhou H, Cheruvanky A, Hu X, Matsumoto T, Hiramatsu N, Cho ME, Berger A, Leelahavanichkul A, Doi K, Chawla LS, Illei GG, Kopp JB, Balow JE, Austin HA 3rd, Yuen PS, Star RA. Urinary exosomal transcription factors, a new class of biomarkers for renal disease. Kidney Int. 2008;74(5):613-21. https://doi.org/10.1038/ki.2008.206.

97. Zhou H, Kajiyama H, Tsuji T, Hu X, Leelahavanichkul A, Vento S, Frank R, Kopp JB, Trachtman H, Star RA, Yuen PS. Urinary exosomal Wilms' tumor-1 as a potential biomarker for podocyte injury. Am J Physiol Renal Physiol. 2013;305(4):F553-9. https://doi.org/10.1152/ajpre nal.00056.2013.

98. Dijkstra S, Birker IL, Smit FP, Leyten GH, de Reijke TM, van Oort IM, Mulders PF, Jannink SA, Schalken JA. Prostate cancer biomarker profiles in urinary sediments and exosomes. J Urol. 2014;191(4):1132-8. https:// doi.org/10.1016/j.juro.2013.11.001.

99. Natasha G, Gundogan B, Tan A, Farhatnia Y, Wu W, Rajadas J, Seifalian AM. Exosomes as immunotheranostic nanoparticles. Clin Ther. 2014;36(6):820-9. https://doi.org/10.1016/j.clinthera.2014.04.019.

100. Pascucci L, Cocce V, Bonomi A, Ami D, Ceccarelli P, Ciusani E, Vigano L, Locatelli A, Sisto F, Doglia SM, Parati E, Bernardo ME, Muraca M, Alessandri G, Bondiolotti G, Pessina A. Paclitaxel is incorporated by mesenchymal stromal cells and released in exosomes that inhibit in vitro tumor growth: a new approach for drug delivery. J Control Release. 2014;192:262-70. https://doi.org/10.1016/j.jconrel.2014.07.042.

101. Haney MJ, Klyachko NL, Zhao Y, Gupta R, Plotnikova EG, He Z, Patel T, Piroyan A, Sokolsky M, Kabanov AV, Batrakova EV. Exosomes as drug delivery vehicles for Parkinson's disease therapy. J Control Release. 2015;207:18-30. https://doi.org/10.1016/j.jconrel.2015.03.033.

102. Kalani A, Kamat PK, Chaturvedi P, Tyagi SC, Tyagi N. Curcumin-primed exosomes mitigate endothelial cell dysfunction during hyperhomocysteinemia. Life Sci. 2014;107(1-2):1-7. https://doi.org/10.1016/j. Ifs.2014.04.018.

103. Yang T, Martin P, Fogarty B, Brown A, Schurman K, Phipps R, Yin VP, Lockman P, Bai S. Exosome delivered anticancer drugs across the blood-brain barrier for brain cancer therapy in Danio rerio. Pharm Res. 2015;32(6):2003-14. https://doi.org/10.1007/s1 1095-014-1593-y.

104. Batrakova EV, Kim MS. Using exosomes, naturally-equipped nanocarriers, for drug delivery. J Controlled Release. 2015;219:396-405. https:// doi.org/10.1016/j.jconrel.2015.07.030.

105. Wahlgren J, De LKT, Brisslert M, Vaziri Sani F, Telemo E, Sunnerhagen $P$, Valadi $\mathrm{H}$. Plasma exosomes can deliver exogenous short interfering RNA to monocytes and lymphocytes. Nucleic Acids Res. 2012;40(17):e130. https://doi.org/10.1093/nar/gks463.

106. Didiot MC, Hall LM, Coles AH, Haraszti RA, Godinho BM, Chase K, Sapp E, Ly S, Alterman JF, Hassler MR, Echeverria D, Raj L, Morrissey DV, DiFiglia M, Aronin N, Khvorova A. Exosome-mediated delivery of hydrophobically modified siRNA for huntingtin mRNA silencing. Mol Ther. 2016;24(10):1836-47. https://doi.org/10.1038/mt.2016.126.

107. Yang T, Fogarty B, LaForge B, Aziz S, Pham T, Lai L, Bai S. Delivery of small interfering RNA to inhibit vascular endothelial growth factor in Zebrafish Using natural brain endothelia cell-secreted exosome nanovesicles for the treatment of brain cancer. AAPS J. 2017;19(2):475-86. https://doi.org/10.1208/s12248-016-0015-y.

108. Jang SC, Kim OY, Yoon CM, Choi DS, Roh TY, Park J, Nilsson J, Lotvall J, Kim YK, Gho YS. Bioinspired exosome-mimetic nanovesicles for targeted delivery of chemotherapeutics to malignant tumors. ACS Nano. 2013;7(9):7698-710. https://doi.org/10.1021/nn402232g.

109. Camussi G, Deregibus MC, Cantaluppi V. Role of stem-cell-derived microvesicles in the paracrine action of stem cells. Biochem Soc Trans. 2013;41(1):283-7. https://doi.org/10.1042/bst20120192.

110. Xin H, Li Y, Cui Y, Yang JJ, Zhang ZG, Chopp M. Systemic administration of exosomes released from mesenchymal stromal cells promote functional recovery and neurovascular plasticity after stroke in rats. J Cereb Blood Flow Metab. 2013;33(11):1711-5. https://doi.org/10.1038/jcbfm .2013 .152$.

111. Shimbo K, Miyaki S, Ishitobi H, Kato Y, Kubo T, Shimose S, Ochi M. Exosome-formed synthetic microRNA-143 is transferred to osteosarcoma cells and inhibits their migration. Biochem Biophys Res Commun. 2014;445(2):381-7. https://doi.org/10.1016/j.bbrc.2014.02.007.

112. Syn NL, Wang L, Chow EK, Lim CT, Goh BC. Exosomes in cancer nanomedicine and immunotherapy: prospects and challenges. Trends Biotechnol. 2017;35(7):665-76. https://doi.org/10.1016/j.tibte ch.2017.03.004

113. Mignot G, Roux S, Thery C, Segura E, Zitvogel L. Prospects for exosomes in immunotherapy of cancer. J Cell Mol Med. 2006;10(2):376-88. 
114. Escudier B, Dorval T, Chaput N, Andre F, Caby MP, Novault S, Flament C, Leboulaire C, Borg C, Amigorena S, Boccaccio C, Bonnerot C, Dhellin O, Movassagh M, Piperno S, Robert C, Serra V, Valente N, Le Pecq JB, Spatz A, Lantz O, Tursz T, Angevin E, Zitvogel L. Vaccination of metastatic melanoma patients with autologous dendritic cell (DC) derived-exosomes: results of thefirst phase I clinical trial. J Transl Med. 2005;3(1):10. https:// doi.org/10.1186/1479-5876-3-10.

115. Besse B, Charrier M, Lapierre V, Dansin E, Lantz O, Planchard D, Le Chevalier T, Livartoski A, Barlesi F, Laplanche A, Ploix S, Vimond N, Peguillet I, Thery C, Lacroix L, Zoernig I, Dhodapkar K, Dhodapkar M, Viaud S, Soria JC, Reiners KS, Pogge von Strandmann E, Vely F, Rusakiewicz S, Eggermont A, Pitt JM, Zitvogel L, Chaput N. Dendritic cell-derived exosomes as maintenance immunotherapy after first line chemotherapy in NSCLC. Oncoimmunology. 2016;5(4):e1071008. https ://doi.org/10.1080/2162402x.2015.1071008.

116. Hiltbrunner S, Larssen P, Eldh M, Martinez-Bravo MJ, Wagner AK, Karlsson MC, Gabrielsson S. Exosomal cancer immunotherapy is independent of MHC molecules on exosomes. Oncotarget. 2016;7(25):38707-17. https://doi.org/10.18632/oncotarget.9585.

117. Naslund TI, Gehrmann U, Qazi KR, Karlsson MC, Gabrielsson S. Dendritic cell-derived exosomes need to activate both $T$ and $B$ cells to induce antitumor immunity. J Immunol (Baltimore, Md: 1950). 2013;190(6):2712-9. https://doi.org/10.4049/jimmunol.1203082.

118. Theodoraki MN, Hoffmann TK, Whiteside TL. Separation of plasmaderived exosomes into $\mathrm{CD} 3((+))$ and $\mathrm{CD} 3((-))$ fractions allows for association of immune cell and tumour cell markers with disease activity in HNSCC patients. Clin Exp Immunol. 2018. https://doi.org/10.1111/ cei.13113.

119. Sharma $P$, Allison JP. The future of immune checkpoint therapy. Science (New York, NY). 2015;348(6230):56-61. https://doi.org/10.1126/scien ce.aaa8172.

120. Bianco NR, Kim SH, Morelli AE, Robbins PD. Modulation of the immune response using dendritic cell-derived exosomes. Methods Mol Biol (Clifton, NJ). 2007;380:443-55. https://doi.org/10.1007/978-1-59745 -395-0_28.

121. Pitt JM, Andre F, Amigorena S, Soria JC, Eggermont A, Kroemer G, Zitvogel L. Dendritic cell-derived exosomes for cancer therapy. J Clin Investig. 2016;126(4):1224-32. https://doi.org/10.1172/jci81137.

122. Record M, Carayon K, Poirot M, Silvente-Poirot S. Exosomes as new vesicular lipid transporters involved in cell-cell communication and various pathophysiologies. Biochem Biophys Acta. 2014;1841(1):10820. https://doi.org/10.1016/j.bbalip.2013.10.004.

123. Sluijter JP, Verhage V, Deddens JC, van den Akker F, Doevendans PA. Microvesicles and exosomes for intracardiac communication. Cardiovasc Res. 2014;102(2):302-11. https://doi.org/10.1093/cvr/cvu022.

124. Hulsmans M, Holvoet P. MicroRNA-containing microvesicles regulating inflammation in association with atherosclerotic disease. Cardiovasc Res. 2013;100(1):7-18. https://doi.org/10.1093/cvr/cvt161.

125. Coleman ML, Sahai EA, Yeo M, Bosch M, Dewar A, Olson MF. Membrane blebbing during apoptosis results from caspase-mediated activation of ROCK I. Nat Cell Biol. 2001;3(4):339-45. https://doi.org/10.1038/35070 009.

126. Hristov M, Erl W, Linder S, Weber PC. Apoptotic bodies from endothelial cells enhance the number and initiate the differentiation of human endothelial progenitor cells in vitro. Blood. 2004;104(9):2761-6. https:// doi.org/10.1182/blood-2003-10-3614.

127. Daleke DL. Regulation of transbilayer plasma membrane phospholipid asymmetry. J Lipid Res. 2003;44(2):233-42. https://doi.org/10.1194/jlr. R200019-JLR200.

128. Loyer $\mathrm{X}$, Vion AC, Tedgui A, Boulanger CM. Microvesicles as cell-cell messengers in cardiovascular diseases. Circ Res. 2014;114(2):345-53. https://doi.org/10.1161/circresaha.113.300858.

129. Simpson RJ, Jensen SS, Lim JW. Proteomic profiling of exosomes: current perspectives. Proteomics. 2008;8(19):4083-99. https://doi. org/10.1002/pmic.200800109.

130. Choi DS, Kim DK, Kim YK, Gho YS. Proteomics of extracellular vesicles: exosomes and ectosomes. Mass Spectrom Rev. 2015;34(4):474-90. https://doi.org/10.1002/mas.21420.

131. Esser J, Gehrmann U, D'Alexandri FL, Hidalgo-Estevez AM, Wheelock CE, Scheynius A, Gabrielsson S, Radmark O (2010) Exosomes from human macrophages and dendritic cells contain enzymes for leukotriene biosynthesis and promote granulocyte migration. J Allergy Clin Immunol 126(5):1032-40, 1040.e1031-4. https://doi.org/10.1016/j. jaci.2010.06.039.

132. Laulagnier K, Grand D, Dujardin A, Hamdi S, Vincent-Schneider H, Lankar D, Salles JP, Bonnerot C, Perret B, Record M. PLD2 is enriched on exosomes and its activity is correlated to the release of exosomes. FEBS Lett. 2004;572(1-3):11-4. https://doi.org/10.1016/j.febslet.2004.06.082.

133. Alonso R, Rodriguez MC, Pindado J, Merino E, Merida I, Izquierdo M. Diacylglycerol kinase alpha regulates the secretion of lethal exosomes bearing Fas ligand during activation-induced cell death of T lymphocytes. J Biol Chem. 2005;280(31):28439-50. https://doi.org/10.1074/jbc. M501112200

134. Trajkovic K, Hsu C, Chiantia S, Rajendran L, Wenzel D, Wieland F, Schwille P, Brugger B, Simons M. Ceramide triggers budding of exosome vesicles into multivesicular endosomes. Science (New York, NY). 2008;319(5867):1244-7. https://doi.org/10.1126/science.1153124.

135. Subra C, Laulagnier K, Perret B, Record M. Exosome lipidomics unravels lipid sorting at the level of multivesicular bodies. Biochimie. 2007;89(2):205-12. https://doi.org/10.1016/j.biochi.2006.10.014.

136. Falguieres T, Castle D, Gruenberg J. Regulation of the MVB pathway by SCAMP3. Traffic (Copenhagen, Denmark). 2012;13(1):131-42. https:// doi.org/10.1111/j.1600-0854.2011.01291.x.

137. Muller L, Hong CS, Stolz DB, Watkins SC, Whiteside TL. Isolation of biologically-active exosomes from human plasma. J Immunol Methods. 2014;411:55-65. https://doi.org/10.1016/j.jim.2014.06.007.

138. Thery C, Amigorena S, Raposo G, Clayton A. Isolation and characterization of exosomes from cell culture supernatants and biological fluids. Curr Protoc Cell Biol. 2006;3:3.22. https://doi.org/10.1002/0471143030 .cb0322s30.

139. Zlotogorski-Hurvitz A, Dayan D, Chaushu G, Korvala J, Salo T, Sormunen $R$, Vered M. Human saliva-derived exosomes: comparing methods of isolation. J Histochem Cytochem. 2015;63(3):181-9. https://doi. org/10.1369/0022155414564219.

140. Liga A, Vliegenthart AD, Oosthuyzen W, Dear JW, KersaudyKerhoas M. Exosome isolation: a microfluidic road-map. Lab Chip. 2015;15(11):2388-94. https://doi.org/10.1039/c5lc00240k.

141. Kastelowitz N, Yin H. Exosomes and microvesicles: identification and targeting by particle size and lipid chemical probes. Chembiochem Eur J Chem Biol. 2014;15(7):923-8. https://doi.org/10.1002/cbic.201400043.

142. Rupert DL, Lasser C, Eldh M, Block S, Zhdanov VP, Lotvall JO, Bally M, Hook F. Determination of exosome concentration in solution using surface plasmon resonance spectroscopy. Anal Chem. 2014;86(12):5929_ 36. https://doi.org/10.1021/ac500931f.

143. Zhuang X, Xiang X, Grizzle W, Sun D, Zhang S, Axtell RC, Ju S, Mu J, Zhang L, Steinman L, Miller D, Zhang HG. Treatment of brain inflammatory diseases by delivering exosome encapsulated anti-inflammatory drugs from the nasal region to the brain. Mol Ther. 2011;19(10):1769-79. https://doi.org/10.1038/mt.2011.164.

144. Tian Y, Li S, Song J, Ji T, Zhu M, Anderson GJ, Wei J, Nie G. A doxorubicin delivery platform using engineered natural membrane vesicle exosomes for targeted tumor therapy. Biomaterials. 2014;35(7):2383-90. https://doi.org/10.1016/j.biomaterials.2013.11.083.

145. Rani S, Ryan AE, Griffin MD, Ritter T. Mesenchymal stem cell-derived extracellular vesicles: toward cell-free therapeutic applications. Mol Ther. 2015;23(5):812-23. https://doi.org/10.1038/mt.2015.44.

146. Ohno S, Takanashi M, Sudo K, Ueda S, Ishikawa A, Matsuyama N, Fujita K, Mizutani T, Ohgi T, Ochiya T, Gotoh N, Kuroda M. Systemically injected exosomes targeted to EGFR deliver antitumor microRNA to breast cancer cells. Mol Ther. 2013;21(1):185-91. https://doi.org/10.1038/ mt.2012.180.

147. Alvarez-Erviti L, Seow Y, Yin H, Betts C, Lakhal S, Wood MJ. Delivery of siRNA to the mouse brain by systemic injection of targeted exosomes. Nat Biotechnol. 2011;29(4):341-5. https://doi.org/10.1038/nbt.1807.

148. Lv LH, Wan YL, Lin Y, Zhang W, Yang M, Li GL, Lin HM, Shang CZ, Chen YJ, Min J. Anticancer drugs cause release of exosomes with heat shock proteins from human hepatocellular carcinoma cells that elicit effective natural killer cell antitumor responses in vitro. J Biol Chem. 2012;287(19):15874-85. https://doi.org/10.1074/jbc.M112.340588.

149. Zhao Y, Haney MJ, Gupta R, Bohnsack JP, He Z, Kabanov AV, Batrakova EV. GDNF-transfected macrophages produce potent 
neuroprotective effects in Parkinson's disease mouse model. PLoS ONE. 2014;9(9):e106867. https://doi.org/10.1371/journal.pone.0106867.

150. Zeelenberg IS, Ostrowski M, Krumeich S, Bobrie A, Jancic C, Boissonnas A, Delcayre A, Le Pecq JB, Combadiere B, Amigorena S, Thery C. Targeting tumor antigens to secreted membrane vesicles in vivo induces efficient antitumor immune responses. Can Res. 2008;68(4):1228-35. https://doi.org/10.1158/0008-5472.can-07-3163.

151. Haney MJ, Zhao Y, Harrison EB, Mahajan V, Ahmed S, He Z, Suresh P, Hingtgen SD, Klyachko NL, Mosley RL, Gendelman HE, Kabanov AV,
Batrakova EV. Specific transfection of inflamed brain by macrophages: a new therapeutic strategy for neurodegenerative diseases. PLOS ONE. 2013;8(4):e61852. https://doi.org/10.1371/journal.pone.0061852.

152. Maguire CA, Balaj L, Sivaraman S, Crommentuijn MH, Ericsson M, Mincheva-Nilsson L, Baranov V, Gianni D, Tannous BA, Sena-Esteves $\mathrm{M}$, Breakefield XO, Skog J. Microvesicle-associated AAV vector as a novel gene delivery system. Mol Ther. 2012;20(5):960-71. https://doi. org/10.1038/mt.2011.303.
Ready to submit your research? Choose BMC and benefit from:

- fast, convenient online submission

- thorough peer review by experienced researchers in your field

- rapid publication on acceptance

- support for research data, including large and complex data types

- gold Open Access which fosters wider collaboration and increased citations

- maximum visibility for your research: over 100M website views per year

At BMC, research is always in progress.

Learn more biomedcentral.com/submissions 